\title{
Believing (faith or hypnosis) impacts on the healing of warts performed by neurophysiological mediators
}

\author{
Huseyin Guducuoglu ${ }^{1}$, Serap Gunes Bilgili², Mehmet Arslan ${ }^{3}$
}

\begin{abstract}
Background: Faith and hypnosis methods are applied in many experimental cancer treatments. Practices of religious and psychological healing have a major role in the recovery of tumors. Healing warts by prayer has been used for years, particularly in the Turkish society.

The Hypothesis: This hypothesis maintains that believing is one of the key concepts in the recovery of tumors and also focuses on the effect of believing on the recovery of warts

Evaluation Hypothesis: In people who believe, nerve, endocrine and immune system is activated. NK and T cells in the periphery cause destruction in the wart tissue and also lead to healing in all tissues. According to our hypothesis, believing is the actual trigger for the healing of warts. Both the prayer and the hypnosis methods, in terms of cancer improvement, have been shown in many publications in the literature and have brought a new dimension to cancer recovery.

Conclusion: We hypothesize that believing (prayer or hypnosis) can be effective on the healing of warts through the stimulation of the immune system.
\end{abstract}

Key words: Warts healing, Believing, Hypnosis

\section{Introduction}

The National Center for Complementary and Alternative Medicine (NCCAM) defines complementary and alternative medicine (CAM) as "a group of diverse medical and health care systems, practices, and products that are not presently considered to be part of conventional medicine" (1). Over the last years, the use of CAM for dermatological diseases has remarkably increased (2). Moreover, a significant relationship has been found between some forms of unconventional therapy and some skin disorders, including generalized pruritus and application of cologne, warts and spiritual healing; fungal infections and application of henna, psoriasis and herbal therapy, or spiritual healing; alopecia areata and application of garlic, acne and application of lemon juice, clay, or cosmetics (3).

In the treatment of warts, prayer is a method of unconventional therapy and is frequently used by many people. There is also another concept named "intercessory prayer', which means that a person performs prayer for the benefit of another person. Many people believe that intercessory prayer is very effective in recovering from illnesses $(4,5)$, particularly in the Turkish society (6). In a study on the use of hypnoanalysis, 33 of $41(80 \%)$ consecutive patients were cured, two were lost to follow-up, and six did not respond to treatment (7). Another study investigated the effect of hypnosis on immunity in order to find out whether this effect is the key mechanism in the hypnotic treatment of the genital infection caused by human papillomavirus (HPV). The study reported that hypnosis and medical therapy resulted in a statistically significant reduction both in the surface areas and the numbers of lesions (8).

\section{The hypothesis}

Believing is a crucial part of prayer and hypnosis. When the person truly believes in prayer, some molecules trigger immune responses in the brain and consequently some molecules are synthesized in the brain and induce a variety of immune system cells in the body. As a result, the disappearance of warts becomes obvious. Moreover, when the person focuses on believing while performing prayers or hypnosis, a number of mediators are secreted from the brain (immunoregulatory neuropeptides) and these mediators facilitate the healing of cancer cells by activating several immune system cells such as NK and $\mathrm{T}$ cells. 


\section{Evaluation of the hypothesis}

Most people discuss the effectivity of the procedures used in cancer treatment, but they still ignore the real power of immunity. In some societies, people employ religious methods to eradicate tumors, particularly warts. Nevertheless, to date, no correlation, such as a relationship between the immune response and the eradication of warts, has been clearly explained in any study. However, since medical treatment is the primary method of choice in tumor therapy, believing (prayer or hypnosis) can be used a supportive therapy for enhancing the immunological effects during the healing process.

Traditional methods are commonly used for the eradication of lesions like warts. It is claimed that believing in the prayer method is the key to success in the recovery of warts. Both the prayer and the hypnosis method, in terms of cancer improvement, have been shown in many publications in the literature and have brought a new dimension to cancer recovery. This dimension will open new doors for the intensive studies to be undertaken on the effectivity of believing on the neurophysiological mediators and cancer recovery.

\section{Discussion}

Hypnosis and prayer employ the same path for providing effects on the recovery of illnesses. Barabasz et al. suggest the following hypnotic method for both groups; "Your body has the capacity to overcome the wart virus and to heal the infection. Focus your attention and concentrate on the involved area [pause]. Soon, you may notice a sensation of warmth in the surrounding skin [pause]. Your blood vessels dilate to bring in more and more antibodies and white blood cells; more lymphocytes and natural killer cells [pause]. The virus will be destroyed and carried away [pause]. Protein and oxygen will increase to help build the new, normal, healing tissue as the warts disappear. When you feel the increased warmth, a finger will rise [after observation of finger raise] good. Now your inner mind will lock in on this and maintain this special warmth until the warts are all healed and your skin becomes normal in every way" (8).

In the prayer method, believing in God and the prayers is the key to the healing of warts. A similar study reported that the participants prayed to God via an intercessor (an imam) and their warts were thus recovered. The study also reported that no effects were seen in the participants who did not trust the intercessor's prayers (5). Therefore, believing is a key issue both for prayer and hypnosis.

When the person truly believes in prayer, the nervous, endocrine, and immune systems interact to adapt to infection, inflammation, and tissue injury. Neural control is mediated in several ways: through the neuroendocrine regulation of the secretion of hypothalamic and pituitary hormones, autonomic nervous system-induced activation of epinephrine secretion and of peripheral sympathetic fibers that innervate lymphoid tissue, and sensory neurons that secrete immunoregulatory neuropeptides such as substance $\mathrm{P}$ and somatostatin. These regulatory interactions influence the manifestations and course of disease (9). Substance P and other neuropeptides activate neurokinin-1 receptors, leading to plasma protein extravasation from post-capillary venules. Substance $\mathrm{P}$ is a neuropeptide that is released from nerve endings in many tissues and plays an important role in immunological and inflammatory states, and it is also a mediator of tissue injury, asthma, arthritis, allergy and autoimmune diseases (10).

In a similar way, products of hypothalamicpituitary-adrenal activation may be important factors contributing to the resistance of the negative feedback of cortisol on $\mathrm{CRH}$ and $\mathrm{ACTH}$ secretion associated with depression, and these products may be involved in psychological distress through their effects on serotonin (11). Serotonin, as a neurotransmitter, is thought to cause depression and serotonin reuptake inhibitors, which increase the availability of this transmitter in the synaptic cleft and alleviate the symptoms. Melatonin, which is a hormone secreted by the pineal gland, is best known for its functions in synchronizing the circadian clock and has been implicated in the pathogenesis of cancer. Melatonin is a product of serotonin metabolism. In the biosynthesis of melatonin, the rate-limiting step is the conversion of serotonin to $\mathrm{N}$-acetylserotonin, catalyzed by $\mathrm{N}$ acetyltransferase (12).

HPV-associated malignancies and breast cancers may be more susceptible to immune effects and to the modulation caused by stress and psychological factors. Developments in cancer immunology call attention to other scenarios as well. Accordingly, although a competent immune response may favor eradication of malignant foci, the increased selection pressure may also yield more aggressive and resistant tumor cells. Animal models of cancer progression are instrumental in suggesting neuroendocrine and immunological mediators of stress effects on specific aspects of cancer progression, especially with respect to the role of Natural Killer (NK) cell activity (13).

Very preliminary data seem to show that lymphocyte proliferation and activation may be influenced by the psychological status of the patients. Some cancers like lung cancer may depend not only on tumor characteristics, but also on the psychospiritual status of the individual patient by influencing the immune and neuroendocrine functions, which plays a fundamental role in the control of neoplastic growth (14). Psychoneuroimmunology is the study of interaction between psychological processes and the nervous and immune systems of the 
human body. Communication between the mind and the skin involves the psycho-immuno-endocrinecutaneous system, encompassing the activities of the brain, the immune system and the skin, with participation of different neuropeptides, interleukins, and immune system messengers (15).

Immunity leading to wart regression is essentially universal but poorly understood. Cellular and cytotoxic immunity provided by $\mathrm{T}$ cells and NK cells are necessary for the control of HPV infections, but the exact mechanisms are unknown (16). For the past few decades, scientific investigations on CAM have remarkably advanced and partly supported their medical efficacy through preclinical and clinical experiments. In particular, many investigators have suggested that NK cell activation is one of the critical mechanisms for the biological effects induced by various CAM agents (17). Therefore, NK and T cells are likely to have a major role in the destruction of warts and thus further studies on wart healing are warranted to focus on these cells.

This hypothesis takes its virtue from the common believing among Turkish people that warts heal via prayers without using any medical treatment. This hypothesis is unique because it will provide important suggestions for future studies.

\section{Conflict of Interest}

The authors declare no potential conflicts of interest with respect to the research, authorship, and/or publication of this article.

\section{References}

1. National Center For Complementary and alternative medicine. What is complementary and alternative medicine (CAM)? Publication No. D156. 2002, URL http://nccam.nih.gov/health/whatiscam/ (accessed 30 January 2008)

2. Magin PJ, Adams J, Heading GS, Pond DC, Smith W Complementary and alternative medicine therapies in acne, psoriasis, and atopic eczema: results of a qualitative study of patients' experiences and perceptions. J Altern Complement Med, 2006, 12: 451-457.

3. Gönül M, Gül U, Cakmak SK, Kiliç S. Unconventional medicine in dermatology outpatients in Turkey. Int Dermatol, 2009, 48(6):639-44.

4. Benson H., Dusek J. A., Sherwood J. B., et al. Study of the therapeutic effects of intercessory prayer (STEP) in cardiac bypass patients: A multicenter randomized trial of uncertainty and certainty of receiving intercessory prayer. American Heart Journal, 2006, 151(4): 934-942.
5. Hoşrik EM, Cüceloğlu AE, Erpolat S. Therapeutic Effects of Islamic Intercessory Prayer on Warts. J Relig Health, 2014, Feb 18. [Epub ahead of print]

6. Bilgili SG, Ozkol HU, Karadag AS, Calka O.The use of complementary and alternative medicine among dermatology outpatients in Eastern Turkey. Hum Exp Toxicol, 2014, 33(2):214-21.

7. Ewin DM. Hypnotherapy for warts (verruca vulgaris): 41 consecutive cases with 33 cures. Am J Clin Hypn, 1992, 35(1): $1-10$

8. Barabasz A, Higley L, Christensen C, Barabasz M. Efficacy of hypnosis in the treatment of human papillomavirus (HPV) in women: rural and urban samples. Int J Clin Exp Hypn 2010, 58(1):102-21.

9. Levin J. How faith heals: a theoretical model. Explore (NY). 2009, 5(2):77-96.

10. Castellani ML, Galzio RJ, Felaco P, Tripodi D, Toniato E, De Lutiis MA, Conti F, Fulcheri M, Conti C, Theoharides TC, Caraffa A, Antinolfi P, Felaco M, Tete S, Pandolfi F, Shaik-Dasthagirisaheb YB. VEGF, substance P and stress, new aspects: a revisited study. J Biol Regul Homeost Agents, 2010, 24(3):229-37

11. Hurwitz EL, Morgenstern H. Immediate and longterm effects of immune stimulation: hypothesis linking the immune response to subsequent physical and psychological wellbeing. Med Hypotheses, 2001, 56(6):620-4.

12. Panzer A. Depression or cancer: the choice between serotonin or melatonin? Med Hypotheses, 1998, 50(5):3857.

13. Ben-Eliyahu S, Page GG, Schleifer SJ. Stress, NK cells, and cancer: Still a promissory note. Brain Behav Immun, 2007, 21(7):881-7.

14. Lissoni P, Messina G, Balestra A, Colciago M, Brivio F, Fumagalli L, Fumagalli G, Parolini D.Efficacy of cancer chemotherapy in relation to synchronization of cortisol rhythm, immune status and psychospiritual profile in metastatic non-small cell lung cancer. In Vivo, 2008, 22(2):257-62

15. Lugović-Mihić L, Ljubesić L, Mihić J, Vuković-Cvetković V, Troskot N, Situm M. Psychoneuroimmunologic aspects of skin diseases. Acta Clin Croat, 2013, 52(3):337-45.

16. Leiding JW, Holland SM. Warts and all: human papillomavirus in primary immunodeficiencies. J Allergy Clin Immunol, 2012, 130(5):1030-48.

17. Cooper EL. The immune system and complementary and alternative medicine. Evid Based Complement Alternat Med, 2007, 4(Suppl 1):5-8.

Copyright (C) 2014 The Author(s); This is an open-access article distributed under the terms of the Creative Commons Attribution License (http://creativecommons.org/licenses/by/4.0), which permits unrestricted use, distribution, and reproduction in any medium, provided the original work is properly cited. 